\title{
The Role of Teaching History for a Nation-Building Process in a Post-Conflict Society: The Case of Macedonia
}

\author{
Biljana Popovska ${ }^{*}$
}

\section{Introduction}

The theoretical framework of this article is based on several published works whose content deals with history teaching as a key mechanism of justice in transitional societies. ${ }^{1}$ Then, it draws from the work of the Center for Democracy and Reconciliation in Southeast Europe and their project "Clio in the Balkans" and the Joint History Textbook Project. In addition, there are materials from interviews with Macedonian and Albanian history teachers, experts, and government representatives selected from the participants in the Macedonian project presented at a United States Institute of Peace conference in Washington, D.C. in November 2005.

\section{Unite or Divide?}

In societies recovering from violent conflict, questions of how to deal with the past are sensitive, especially when they involve memories of widespread victimization, death, and destruction. It is very often the case that, in the wake of violence, political leaders and others seem to prefer social amnesia to the study of their society's recent history, as they try to "move forward" and promote stability.

Therefore, the question arises of whether the teaching of history could help transitional societies become more democratic, and whether it can contribute to the development of empathy for, or even social cohesion among, former enemies in societies in which some groups were marginalized or were deprived of certain rights. Going further, can history teaching reinforce other transitional justice processes, such as truth telling and legal accountability for crimes that had been committed in the past? Finally,

\footnotetext{
* Mrs Popovska is a lecturer at the Military academy of the Republic of Macedonia that is an associate member of the State University Goce Delchev, Shtip. She holds an MA in International relations in conflict resolution from University "Sts. Cyril and Methodius," Skopje Faculty of Philosophy. She was a visiting research fellow at the George C. Marshall European Center for Security Studies (Summer 2013). Her area of research includes post conflict societies and transitional justice.

1 Elizabeth A. Cole and Judy Barsalou, Unite or Divide? The Challenges of Teaching History in Societies Emerging from Violent Conflict, Special USIP Report on a conference held on 21 November 2005 at USIP in Washington (Washington, D.C.: United States Institute of Peace, June 2006; available at http://www.usip.org/publications/unite-or-divide-challengesteaching-history-societies-emerging-violent-conflict; Mirela-Luminita Murgescu, "Rewriting School Textbooks as a Tool of Understanding and Stability," Southeast European and Black Sea Studies 2:1 (2002): 90-104, available at http://dx.doi.org/10.1080/14683850208454674; and Elizabeth A. Cole, "Transitional Justice and the Reform in History Education," International Journal on Transitional Justice 1 (2007); available at http://ijtj.oxfordjournals.org/ content/1/1/115.short.
} 
can teaching history promote belief in the rule of law, resistance to a culture of impunity, and greater trust in public institutions, including schools themselves?

The United States Institute of Peace conference convened on this topic in Washington, D.C. in November 2005 raised the issue of the content of post-conflict history education, which raised additional concerns about developing and adopting new history curricula. The issues to be considered include:

- Who decides what version(s) of history will be taught?

- What impact do those choices have on promoting stable, cohesive, and tolerant societies?

- What is the relationship between the (re)writing of history by academic historians and the development of secondary-school history textbooks?

- What impact do transitional justice processes have on the development of new secondary-school history textbooks and the way history is actually taught in schools?

One particularly problematic issue for post-conflict school systems in divided, multiethnic, and multilingual societies is determining which languages will be used to instruct schoolchildren. Although it is important for children in a multilingual country to learn the language (and, by extension, the culture) of other main groups of citizens in addition to their own mother tongue, having too many official languages in the schools can promote semi-literacy, poor performance, high repetition, and high dropout rates (as is seen in many African countries). At the same time, the rising importance of English as a lingua franca in the global marketplace is increasingly influencing language policies. Ethnic segregation or integration of schools also is an important structural aspect of education. When different ethnic groups are educated separately within the national education system, and especially when one ethnic (or gender) group receives more educational resources than another, such arrangements can convey important overt or hidden messages to students. Cole and Barsalou's report says that some educational systems (such as Macedonia's) permit the use of different history texts in ethnically segregated classrooms. In this case, history instruction in Macedonia is the same for Albanians and Slavs - but only in the sense that each group separately learns a remarkably similar history of victimization by the other, and each claims the same distinctions, such as a longer presence in the region. Another challenge is the decreasing priority given to the teaching of history and the humanities by post-conflict societies intent on preparing their students to compete in the global marketplace, with more emphasis being placed on subjects seen to have practical value, such as foreign languages, math, science, technology, and vocational training. Thus the potential for schools to promote social reconstruction through history education in post-conflict societies is not being fully realized.

In post-conflict countries that receive substantial foreign attention, post-conflict reconstruction increasingly tends to be a transnational process, although "insiders," or locals, are the ones who will have to live with (and take responsibility for) the longterm results of reconstruction and reform work. Outsiders who work on history educa- 
tion reform tend to be from nongovernmental organizations (NGOs) rather than transnational organizations or foreign governments, although some academics from foreign universities also are becoming involved. Often, however, powerful outside actors, particularly funders, view education as a domestic issue that "insiders" are best qualified to tackle. However, they consider other transitional justice processes, such as trials and elections, more deserving of their time and support. On the positive side, outsiders can get insiders engaged in reform processes that are too touchy for locals to handle on their own by bringing together groups that are otherwise disinclined to work together.

Pedagogical reform is attractive as a strategy because it may be less controversial or threatening than attempts immediately after conflict to change historical narratives through curriculum reform. But pedagogy reform is most effective when combined with curriculum reform. ${ }^{2}$

\section{Transitional Justice and Reforming History Education}

History education at the secondary school level also conceptually fits into some aspects of the work of transitional justice, which is another reason that Elizabeth Cole makes the argument that it should have "a place at the table" of transitional justice, meaning that it should be a part of transitional justice planning. Beyond the possibility that educational initiatives - both school-based and non-school-based (the latter would include museums, monuments and other cultural projects) — can help to carry forward the work of transitional justice mechanisms, the question remains of how to allow ordinary people to take ownership of processes of transitional justice. How does creating new approaches to history education relate to the specific goals of transitional justice? The purpose of history education in the modern state has generally been to transmit ideas of citizenship and both the idealized past and the promised future of the community.

2 Presentation by Violeta Petroska-Beshka at the "Unite or Divide?" conference, 21 November 2005, United States Institute of Peace, Washington, D.C. Petroska-Beshka's argument has sparked political controversies in Macedonia. An edition of the website "Balkan Insight" (No. 20, 20 February 2006) described a "storm" of controversy that erupted over PetroskaBeshka's efforts to reform the teaching of history in Macedonia. In a typical comment, Blazhe Ristevski, then the director of the Macedonian Academy of Science and Arts, said, "As a scientist, I can't allow that truth can be found through this kind of 'partnership.' It just adds more petrol to the fire between the two sides." Ljupcho Jordanovski, at that time the Speaker of the Macedonian Parliament, said not enough time had passed since the recent conflict between Macedonian Slavs and Albanians, and objectivity was impossible because "we were all either direct or indirect participants." Countering that such reforms are hard to undertake at any time, Petroska-Beshka argued, "If we don't speak openly about these painful issues, we leave a space to create ethnically colored, opposing versions that will affect the definition of official history." Teachers need strong support from parents, school administrators, and other authorities to teach new curricula and use new pedagogies. Such support must be ongoing, as teachers suffer from burnout, especially in high-stress situations. It is this group of teachers from Petroska-Beshka's project that is the target population of the research part of this paper. They have been trained, and enough time has passed for us to learn something from their experience. 
History and civics textbooks in most societies present an "official" story highlighting narratives that shape contemporary patriotism. Education helps articulate relations between state and society and sets the boundaries and terms of citizenship. If the representation of a group's past is now recognized as an integral part of its identity, and this identity includes not only how one views one's own group but also the groups designated as "other" or as adversaries, then understandings of history are crucial to a society's ability to reckon with the difficult past for the sake of a more just future.

Cole also posits that revisions in history education methodology, as well as content, can serve the goal of deepening democracy by enhancing critical thinking and empathy skills, the willingness to question simplistic models and the ability to disagree about interpretations of the past, and their implications for present social issues without resorting to violence. Teaching, which presents history to students as an academic discipline with widely accepted standards and methodologies, rather than as a political tool or expression of nationalism, can help make the study of history "at its best ... not simply a collection of facts, not a politically sanctioned listing of indisputable 'truths,' but an ongoing means of collective self-discovery about the nature of our society." 3

Cole also points out that one of the main insights from the USIP "Unite or Divide?" conference is that reforming the way history is taught in a time of political transition should take priority in many contexts over the history curriculum and over content revision, although pedagogy and teacher training are still very much under-addressed when history education reform is under discussion. Traditionally, history education has been a conservative project, closely controlled at the national level, intended to build group cohesion and loyalty to the state, and in the past it has focused on military and political history and the role of political and military elites (generally men). The emphasis was on learning facts, not on inquiry, discussion, debate, nor on drawing connections between problems in contemporary society and the past. Finally, the historical narrative was presented as something fixed whose legitimacy was unquestionable: there was little attempt to expose students to history as a field of science, to historiography, to the ways in which historical knowledge is constructed and understandings of which might allow students "to understand why accounts of the same event might differ." 4

While this has changed dramatically in Western Europe and North America, and is beginning to change in other regions, it is generally true of history content and pedagogy in transitional countries prior to and during conflict and/or dictatorship.

Secondary school history is much more politically sensitive than university-level history or the work of academic historians, and often lags behind them in terms of pro-

3 Eric Foner, Who Owns the Past? Rethinking the Past in a Changing World (New York: Hill and Wang, 2002), 88.

4 Alison Kitson, "History Teaching and Reconciliation in Northern Ireland," in Teaching the Violent Past: History Education and Reconciliation, ed. Elizabeth A. Cole (Lanham, MD: Rowman \& Littlefield, 2007). 
gressiveness and risk taking, because younger students are seen as highly impressionable and politically "pure."

It is partially for this reason - although also for more practical reasons, such as limited resources and the complex procedures of program and curriculum reforms and textbook creation, production, and distribution - that the reformation of history textbooks in the aftermath of massive human rights abuses tends to take a long time. Elizabeth Jelin, another author Cole cites, suggests that the processes of incorporation of difficult issues into the education system have a very strong institutional component, since they require reaching a minimum consensus and an institutionally legitimized version of what took place (Jelin was writing specifically about the case of post-conflict Argentina). If the political conflict is not yet resolved, it is impossible to elaborate such a version of past events.

Other obstacles to reforming history education are more practical than political, but no less important to consider. One such obstacle is the low priority placed on history as well as literature, arts and social studies, compared to education in math, science, technology and vocational training in many parts of the world. This is true for developing countries with scarce resources for education as much as it is for developed nations.

Cole further points out the conclusions of the participants in the 2005 "Unite or Divide?" conference, who included South African, Rwandan, Macedonian, Colombian, Northern Irish, Sri Lankan, and Lebanese educators:

$[\mathrm{H}]$ istory teachers generally are under enormous pressure in post-conflict societies to play too many roles - from psychologist and guidance counselor to conflict resolution expert and mediator. Education reformers, especially those from the outside, also typically expect teachers to be agents of fundamental social change. Yet evidence from Northern Ireland shows that teachers are not comfortable being leading agents of social change, and they doubt that anything they teach can counter what the history students learn at home. In the most extreme cases, in highly charged political contexts where adopting new teaching approaches or texts may lead to threats to teachers' physical safety, they will be especially likely to shy away from innovation. ${ }^{5}$

Finally, Cole points out that some surveys indicate that history as a school subject is one of the most unpopular subjects with students, and that adults also have unfavorable memories of their history classes - despite the fact that nonacademic vehicles for history, such as movies, popular histories, the creation of family genealogies, and historical sites are popular. This may indicate that reforming the history classroom to support the work of transitional justice will be a very difficult process. But it may also show that the problem is not that the past cannot be made compelling for students, but rather that it has rarely been done thus far.

However, there are some promising methodologies that lie in the rapidly expanding area of new media. Interactive multimedia websites can capture historical material in a

5 Michael Ignatieff, The Warrior's Honor: Ethnic War and the Modern Conscience (New York: Metropolitan Books, 1998), 173. For accounts of interviews with teachers in Guatemala and Northern Ireland who tackle "difficult issues" in their classrooms, see the chapters by Elizabeth Oglesby and Alison Kitson in Cole, ed., Teaching the Violent Past. 
variety of multilayered printed, visual, audio, and video formats, allowing students to hear the voices of witnesses to recent history and of scholars who use history in their work, including archaeologists and forensic anthropologists. These scholars are able to discuss how they use evidence to arrive at historical conclusions and describe how they conduct their own research through a vast array of sources, including newspapers, museums, official government and nonofficial and nongovernmental sites, in order to create their own primary documents by posting their own accounts of current events and to design and curate their own exhibitions online. New technological approaches to history teaching, fortunately, are not the only sources of hope for a wider role for history education in transitional justice. Two globalizing tendencies in history education (although not without problems of their own) may contribute to a history education that can better complement the work of transitional justice processes. These are "socialsciencization (an increasing focus on contemporary history and on society as opposed to the state) and a steady globalization." 6 The global spread of these two tendencies is well attested by a recent report on dramatic changes in Chinese history textbooks. The new books focus more on society, economics, culture, and international history, and less on ideology, leaders, wars, and political history. In his comments on the new textbooks, education professor and textbook author Zhou Chunsheng refers to global trends in history education: "History does not belong to emperors or generals ... it belongs to the people. It may take some time for others to accept this, naturally, but a similar process has long been underway in Europe and the United States." cle points out, gains in the area of giving students access to the voices and experiences of many new actors are offset by other problems: Chinese history textbooks do not yet address disastrous periods in the history of the People's Republic (such as the mass starvation that accompanied Chairman Mao's "Great Leap Forward"), and may in fact deflect students' attention from recent political events. But the new approaches to history may allow Chinese students to gain some of the skills and perspectives to approach, at some later point in their lives, the difficult past their parents and grandparents lived through.

Cole posits that another promising sign for the likelihood that history education can be the subject of meaningful and effective reforms is the gradual increase in attention paid to it and the increase in experts from a variety of disciplines (academic history, education, human rights, public health, and child and adolescent psychology) working in the field. There has been an increase in international learning about the field of history education, as there was in earlier decades in transitional justice in the development

6 Jacques E.C. Hymans, "What Counts as History and How Much Does History Count? The Case of French Secondary Education," in The Nation, Europe and the World: Textbooks and Curricula in Transition, ed. Hanna Schissler and Yasemin Nuhoglu Soysal (New York and Oxford: Berghahn Books, 2005), 61, citing David John Frank, et al., "What Counts as History: A Cross-National and Longitudinal Study of University Curricula," in Comparative Education Review 44 (2000): 29-53.

7 Joseph Kahn, "Where's Mao? Chinese Revise History Books," in The New York Times, 1 September 2006. 
of NGOs, and of women's and indigenous rights. Valuable studies - some of the first large-scale comparative ones in the field - were carried out by the Human Rights Center at the University of California, Berkeley, in close collaboration with local human rights and education specialists. At the level of transnational institutions, UNESCO has supported studies of education and its connection to post-conflict social reconstruction. In Europe, the Georg Eckert Institute, Euroclio, and the Thessaloniki-based Center for Democracy and Reconciliation in Southeast Europe have all been active in spearheading collaborative international projects to examine and reform history textbooks, curricula, and teaching practices. Conferences and exchanges for educators from different transitional societies to share their experiences and approaches, often including South African, Northern Irish, German, and Polish educators, have become more common.

Cole concludes her article with several recommendations, drawn primarily from the Carnegie Council study and the USIP-sponsored conference mentioned above. The first is that educators and historians should be involved from the beginning in planning transitional justice interventions. Educators as well as legal scholars and political and religious leaders should be given a stake in the work of transitional justice.

One prime topic might be to investigate what the relationship between historical/ history textbook commissions and history education reform can tell us about truth commissions and history education, since more is known about changes in history education in the aftermath of historical commissions. Although historical commissions are not yet counted among mainstream transitional justice mechanisms, they have been used in long-term efforts to reckon with the past, particularly in Europe, and are currently being tried in the context of several historical conflicts. Textbooks have been revised as a result of the findings of historical commissions, and are often cited as important components of furthering long-term reconciliation between Germany and several World War II-era victim groups, particularly France, Poland, and the Czech Republic. There is ample documentation of the changes in narratives that young people in Germany, France, Poland, and the Czech Republic have learned as a result of history education reform, particularly through the studies done by the Georg Eckert Institute, which both consults on history education reform as well as carries out research on history textbooks as they relate to conflict and democracy. The evidence from European historical commissions and history education reform may well be useful in trying to assess the effects that history education revision, as a long-term follow up to truth and reconciliation commissions (TRCs), may have on intergroup relations.

\section{School Textbook Revision and Stability}

Mirela-Luminita Murgescu, in an article titled "Rewriting School Textbooks as a Tool of Understanding and Stability," says that in spite of all particularities of the different countries in the region, there are obviously some common problems of history teaching in all Southeast European countries. ${ }^{8}$ The tendency to present an ethnocentric vision of

8 See Mirela-Luminita Murgescu, "Rewriting School Textbooks as a Tool of Understanding and Stability," Southeast European and Black Sea Studies 2:1 (2002): 90-104; available at http://dx.doi.org/10.1080/14683850208454674. 


\section{THE QUARTERLY JOURNAL}

history, which presents "the nation" as the main historical actor even for periods when it was not relevant, or for processes that happened at a local or regional level, has been stressed in many countries by the didactic division between national history and world history, which are taught in different grades, as distinct disciplines. Equally significant is the tendency to present all of history as a continuous heroic struggle of the home nation, which had to resist the hostility of the rest of the world. Such a sharp division between "we" and "they" allows textbook authors to explain present dissatisfactions as the outcome of the malicious action of external factors.

Another sensitive point in textbooks, especially in history textbooks, is the inability to rise above a one-sided vision of history. In this perspective, each textbook presents exclusively the version of history of its own political, national, or ethnic community. It is usually only the experience of one's own ethnic group with other groups that is presented, but not the experiences the "others" have with "us." The experiences of Croats during the interwar period in Yugoslavia are not included in Serbian textbooks, just as the experience of Serbian families during the Ustasha regime are at best presented at a superficial level in Croat textbooks. ${ }^{9}$

Another common feature of history teaching in the region in general is the authoritarian pattern of the teaching process, where the pupils are asked only to learn what the teacher teaches them, while the teaching of analytical patterns and of critical discussion are almost completely absent. It is obvious that such an outdated way of teaching history is less effective, yet the most simplistic historical information still influences the younger generation, and the lack of analytical abilities increases the likelihood that the youngsters will accept uncritically the most simplistic historical narratives.

Murgescu recommends that the first task should be the removal of erroneous, false, exaggerated and/or offending statements about other nations, peoples, social and ethnic groups. In this respect there exists significant experience in Western Europe, and the South East European countries also made some progress in the late 1980s and the 1990s. ${ }^{10}$

Removing the offending elements is just one part of the job. In fact, an expurgated history is less attractive, and the pupils will learn from their parents what they no longer learn from school. Therefore, there is a crucial need to insert something in the place of the hatred that had been removed. A first step in this direction would be to create a database of sources and narratives showing instances of cooperation between the neighboring peoples, the benefits of mutual understanding, and the disadvantages

9 Wolfgang Höpken, "Textbooks and Reconciliation in Southeastern Europe," in Culture and Reconciliation in Southeastern Europe, International Conference, Thessaloniki, Greece, 2629 June 1997 (Thessaloniki: Paratiritis, 1997). Cited in Murgescu 2002, p.96/8.

10 She refers to Evangelos Kofos (1999), "Textbooks: The Pendulum of 'Loading' and 'Disarming' History: The Southeastern European Test Case," in Disarming History. International Conference on Combating Stereotypes and Prejudice in History Textbooks of Southeast Europe (Stockholm: Nykopia Tryck AB, 1999), p.23-27. Cited in Murgescu, 2002, p. $96 / 8$. 
of hostility. Then, each party would be encouraged to include in the curricula and in the textbooks episodes or sources from this database.

Improvement of curricula and textbooks should include mainly history, but also other identity-forming disciplines such as civics, geography, literature, and religion, which often disseminate hostility even more effectively than history. For this purpose, the crucial level of action is that of the national school authorities (usually ministries and various national agencies).

In the past, and in other parts of Europe, there have been bilateral textbook conferences backed by the education ministries of the countries involved. These could provide a model for similar conversations in South East Europe. An institution similar to a think tank could also be formed in the region to consider the issue of textbook reform. Such an institution should include distinguished scholars with a wide knowledge of South East European history and culture, and also of European and world history. These scholars should be asked to design and discuss a list of "positive" elements that should be included in the curricula and textbooks; the final list should include short presentations for each entry, in order to allow non-specialists to realize the educational significance of such an approach. Murgescu mentions that the Center for Democracy and Reconciliation in Southeastern Europe, based in Thessaloniki, has already established two committees, which might provide the core of the think tanks that could be asked to prepare the general conference for curricula and textbook improvement in South East Europe.

Murgescu concludes by saying that it is a well-accepted fact that "images of the past commonly legitimate a present social order. It is an implicit rule that participants in any social order must presuppose a shared memory." ${ }^{11}$ In this respect, that the metaphor of school textbooks as the modern equivalents of the village story-tellers is correct. Like story-tellers in non-literate societies, textbooks in history, geography and civics are responsible for conveying to youth what adults believe they should know about their own culture as well as that of other societies. There are, of course, many sources of socialization in modern society, but none compares to textbooks in their capacity to convey uniform, approved, even official versions of what youth should believe. $^{12}$

Rewriting textbooks does not imply only composing new textbooks according to new values and educational aims. This is just one step in a long and difficult process. South East European societies have to manage not only a moderation of historical memory, but also the effort to encourage individual members of society to understand and support the necessity of such changes. Education must open "the ability to develop

11 She refers to Paul Connerton, How Societies Remember (Cambridge: Cambridge University Press, 1989). Cited in Murgescu, 2002, p. 102/14.

12 She refers to Deborah S. Hutton and Howard D. Mehlinger, "International Textbooks Revision. Examples from the United States," in Perceptions of History. International Textbooks Research on Britain, Germany and the United States, ed. Volker R. Berghahn and Hanna Schissler (Oxford: Berg, 1987), 141. Cited in Murgescu, 2002, p. 102/14. 
a historical consciousness" and not to distribute only, as today, "ready historical images." 13

Education programs should not concentrate only on history textbooks. For several years, history textbooks were a primary focus of attention, but similar importance should be placed on civics, geography, literature, music, and art classes. For instance, the literary texts selected for primary education textbooks are one of the most efficient tools for instilling not only knowledge, but also for creating attitudes and a social and historical consciousness. To conclude, an efficient educational policy regarding the rewriting of textbooks in South East Europe as a tool of understanding and stability should take into account some specific prerequisites like the political will of governments and political elites in the region to adjust their education policies according to European standards, and thus to base them on democratic values and civic attitudes. This should include both an extensive study of the collective and national memory in South East Europe, linked with analyses of educational policies and textbooks in the last two centuries, and the preparation of a set of concrete changes to be enforced.

\section{The Case of Macedonia}

How does all of the above translate to the case of Macedonia as a post-conflict society? This article has previously mentioned Prof. Violeta Petroska-Beshka's work with history teachers in Republic of Macedonia. It is interesting to mention that the selected teachers were from particularly conflict-torn areas of Macedonia (Kumanovo, Tetovo, and Skopje), and some of them even belonged to the category of conflict-vulnerable citizens. Although ten years have passed since the conflict, I decided to interview these teachers since, aside from the actual work they did on the lesson, they went through a training program about understanding conflicts - thus, they can be said to have gone through the indirect process of a reconciliation program. However, my aim has been to see whether their perceptions have changed and how they actually view the practice of history teaching in the Republic of Macedonia. As one of the Macedonian respondents who had the role of an expert in the sessions brought up the phrases "Clio in the Balkans," "Center for Democracy and Reconciliation in Southeast Europe," and "Joint History Textbook Project," it may be best to take as a starting point the work of the Center for Democracy and Reconciliation in Southeast Europe (CDRSEE).

The CDRSEE is a non-governmental, non-profit organization that seeks to foster democratic, pluralist, and peaceful societies in South East Europe by advocating principles of social responsibility, sustainable development, and reconciliation among the peoples in the region. Macedonia has been a contributor to that work through its scholars. One of the publications produced by the center, titled Clio in the Balkans, includes contributions from Macedonian scholars. ${ }^{14}$ I shall refer to two articles, the first by

13 She refers to Wolfgang Höpken, ed., Öl ins Feuer? Schulbücher, ethnische Stereotypen und Gewalt in Südosteuropa (Hannover: Verlag Hahnsche Buchhandlung, 1996), p. 120. Cited in Murgescu, 2002, p. 102/14.

14 Christina Koulouri, ed., Clio in the Balkans: The Politics of History Education (Thessaloniki: CDRSEE, 2002); available at www.cdsee.org/pdf/clio_in_the_balkans.pdf. 
Nikola Jordanovski, the second by Emilija Simoska. Their analyses should provide a full picture of history teaching in Macedonia and raise some issues for consideration.

In her Appendix on educational systems and history teaching in FYR Macedonia, Emilija Simoska says that national history is not a separate subject in any school in Macedonia, and it is only taught as a part of world history. ${ }^{15}$ The main method of teaching is based on the pure presentation of historical information, with almost no evaluation and very little additional information, which is sometimes very difficult for the children to understand. According to Simoska, the Pedagogical Office, which is an expert body of the Ministry for Education, approves all of the textbooks used in history education. Simoska notes that the biggest problems arise with respect to the fact that the same circle of people who write the textbooks also approve them, which makes it difficult to break this circle in order to establish normal competition that would definitively result in better quality (this is the case in spite of an open bid for the writing of new textbooks). The main recent innovation has been in amending the laws on primary and secondary education to allow each school the right to use additional textbooks according to their choice.

Nikola Jordanovski analyzes the treatment of the common Yugoslav history in Macedonian school books with the intention to show how some crucial questions of the former nation's recent history were addressed. ${ }^{16}$ The vocabulary and the style used in the new books are inherited from the old school books, and the message has remained the same as well. Jordanovski states that interethnic violence is a subject one might think would take up more space in the schoolbooks, while there is actually only one passage on that issue in the school book for the fourth year of gymnasium, which will speak for itself when quoted in its totality: "Immediately after the occupation, the occupiers helped by the local traitors started a terrible terror through arrests, deportations, individual and group murders and massacres, mass exterminations of whole national collectivities...."

The Joint History Textbook Project. Another project of the CDRSEE related to Macedonia is the Joint History Textbook Project. As an introduction to this project I shall cite parts of the Preface to the Macedonian edition of Workbook 1 by Irena Stefovska, and will continue with analyses of the media discourse after the textbooks were launched as alternative history textbooks.

Ms. Stefovska writes, "The constant emphasizing of the ethnical, religious and language differences and not respecting the similarities resulting from the joint history leads to stereotyped understanding of the specifics of the history of the region as a whole and each of the nations separately thus creating an image that 'our history is one and unique'." ${ }^{\prime 7}$ She further sates that the difference is not something that should be

15 Emilija Simoska, Appendix, "FYR Macedonia," in Clio in the Balkans, 495-97.

16 Nikola Jordanovski, "Between the Necessity and the Impossibility of a 'National History'," in Clio in the Balkans, 265-76.

17 Preface to the Macedonian edition by Irena Stefoska, p.9, http://www.cdsee.org/jhp/pdf/ WorkBook1_mak.pdf. 
turned into a matter of life or death and something to help the elites rule. Rather, it is an issue we should seek an answer to on behalf of the ethics of knowledge.

Media Discourse. The media discourse that followed the launching of the textbooks in the Republic of Macedonia was rather positive, and promised that the use of the books as alternative materials would be a successful effort and would serve its purpose. However, the use of the acronym FYROM raised issues, and it was followed by defensive statements from contributors to the project saying that not only did they not have concrete input into the content, but in some cases they were even out of town when the textbooks were prepared.

The Voice of the Teachers. It was very interesting to note that none of the interviewees mentioned the use of any "Joint History Textbook Project" material. Only the Macedonian respondent who was involved in the project as an expert pointed out the importance of the project and the amount of work invested into it. Although this question was not explicitly asked, as the interview followed a semi-structured script, it allowed teachers opportunities to comment on it and talk about whether the Joint History Textbook Project had been a success in Macedonia.

One Macedonian respondent stated: "In the text books under the term culture they cover areas from the history of art (literacy and architecture) and do not use the term in its anthropological sense." The same respondent went on: "The actual book writing was preceded by training about theory of conflicts but not getting deeper into conflicts in order to help the project participants [history teachers] make joined lessons on the assigned topics." The respondent said that people are not aware of the stereotypes of the language used in the discourse. During the project they (project participants) did discourse analyses of how they could describe an event as interesting without expressing a particular sympathy for their own ethnic group. Gradually they all realized that the model of representing opinion is left to individual actors. In addition, the respondent said that the type of learning/teaching within the Macedonian state school system is doctrinaire and authoritarian.

One Albanian respondent stated that textbooks used for teaching historical events - especially those related to Albanian history-most often contain unconfirmed historical facts or divert some of the already established findings which are the result of previous research recognized by the world historiography. About the concept of sharing history, the following sample was obtained from an Albanian respondent: "We live with stereotypes. Young Albanians do not know [the] Macedonian language. It seems that the gap between Macedonian and Albanians is even wider after 2001."

The final project product is a published book (one lesson of seven pages) but in a format that includes three alternative versions of the same lesson (the Macedonian version, the Albanian version, and the agreed version). The participants in the project hope that the book will become part of the official high school curriculum. They all agree that the most difficult area in which to reach a consensus has been related to the causes/reasons for the conflict in Macedonia. Some of the work was carried out through homework, and the teachers were grouped as extreme nationalists from differ- 
ent ethnic groups. These teachers had to exchange ideas and work on the material via e-mail correspondence.

An Albanian project participant claimed that after the project he changed a lot, and felt that it was positive experience for him as it changed his point of view towards Macedonian history teachers. However, a Macedonian expert responded as follows: "From what is invested in the teachers, there are weak results. We should all follow the motto of lifelong learning. Values and skills are important."

When asked about the status of history as a school subject, one participant responded, "The curriculum (plans and programs) are prepared by the BRO (Bureau for Development of Education). They have been changed three times since the independence of 1991. After the conflict new textbooks have been made, and for the first time the history of Albanians in the region has been included. There is little information about Vlachs in Macedonia. The greatest portion is the national history of Macedonia, then something about Albanian history, and then comes the rest."

In response to the question of "whether the lessons made during the "Understanding History' project are used in the classrooms," the general answer was negative. As one Macedonian respondent put it, "To use materials in a highly centralized educational system - especially history lessons, in spite of the freedom given to the teachers to be $30 \%$ creative - is not done by the teachers. So they do not supplement their lessons. What they have to teach is mostly high politics, facts and dates, heroes. It is not very interesting for the students, and it is sometimes torturous to have to remember facts."

Responses from teachers and parents depended on the location of the schools, which means additional research would be of use to include places affected by the conflict, where students had to leave their houses and move away, in comparison to places that did not experience conflicts, and places where there is no contact with the Albanian ethnic community. As one Macedonian participant said, "During the conflict the emotions must have been stronger but there is a time distance now."

\section{Conclusions}

There is a quite a lot of work invested in Macedonia related to the teaching of the nation's history. But it seems that the subject gets neglected when it comes to actual classroom practice. Albanians seem to view history teaching in terms of percentages. Some of them use additional materials to teach about Albanian history, and even use books imported from Albania. The Ministry of Education allows the use of additional materials, but it seems that teachers are not particularly eager to use them. Sometimes both Macedonian and Albanian history teachers form their opinion based on word of mouth rather than on reading books. They all agree that silence is a preferred outcome instead of heated debates. It took them a year to write just a few pages of one combined lesson on the recent past, even a lesson that contained three versions (Macedonian, Albanian, and a consensus one). Sometimes, the joint work lasts only as long as the project lasts, and it seems like there is no initiative for sustainability.

Elizabeth Cole's message and Violeta Petroska-Beshka's project both represent efforts to bring people of different ethnicities together to teach them to be open and em- 
brace diversity. Macedonians and Albanians live on the same territory. How can they both look ahead and determine what would make the best state for them going forward? There are many opinions and answers to this question. Each party has its own opinion.

The efforts invested into the projects discussed above have produced some positive results, as we can see from the interviews. But we need to move to the next level. One of the interviewees said, "People will make the effort only if somebody from outside puts them together." This means that civil society in Macedonia is as yet underdeveloped for the task at hand, so external help is necessary. This problem of collective action means that the people of Macedonia are not able to coordinate their actions. Looking to history, and particularly to civil society in history, may give Macedonia models to follow that can help the nation move forward - an effort for which a new approach to teaching the nation's history will be necessary.

Elizabeth Cole's recommendations and the findings drawn from the interviews are a good starting point. There is a necessity to work along these lines, and such work should be institutionalized (such as the revision of history books). Some compromises have been made in the country by signing the Framework Agreement. What is next? Ten years have passed since the period of conflict, but the potential for a relapse still exists. What is the next level? Embracing concepts of civil society is not enough. Contacts between ethnicities are not enough. Either scientific encouragement is needed, or help from outside is required to address the problem of collective action. The answer is to decide to let civil society develop and then act on that decision. 


\section{Bibliography}

Cole, Elizabeth A.. "Transitional Justice and the Reform in History Education." International Journal on Transitional Justice 1 (2007).

Connerton, Paul. How Societies Remember. Cambridge: Cambridge University Press, 1989.

Foner, Eric. Who Owns the Past? Rethinking the Past in a Changing World. New York: Hill and Wang, 2002.

Höpken, Wolfgang. "Textbooks and Reconciliation in Southeastern Europe." In Culture and Reconciliation in Southeastern Europe, 90-104. Vol. 2. Thessaloniki: Paratiritis , 1997.

Höpken, Wolfgang. Öl ins Feuer? Schulbücher, ethnische Stereotypen und Gewalt in Südosteuropa. Hannover: Verlag Hahnsche Buchhandlung, 1996.

Hutton, Deborah S., and Howard D. Mehlinger. "International Textbooks Revision. Examples from the United States." In Perceptions of History. International Textbooks Research on Britain, Germany and the United States, 141. Oxford: Berg, 1987.

Hymans, Jacques E. C.. "What Counts as History and How Much Does History Count? The Case of French Secondary Education." In The Nation, Europe and the World: Textbooks and Curricula in Transition, 61. New York and Oxford: Berghahn Books, , 2005.

Ignatieff, Michael. The Warrior's Honor: Ethnic War and the Modern Conscience. New York: Metropolitan Books, 1998.

Jordanovski, Nikola. "Between the Necessity and the Impossibility of a 'National History." In Clio in the Balkans: The Politics of History Education, 265-76. Thessaloniki: CDRSEE, 2002.

Kitson, Alison. "History Teaching and Reconciliation in Northern Ireland." In Teaching the Violent Past: History Education and Reconciliation. Lanham, MD: Rowman \& Littlefield, 2007.

Kofos, Evangelos. "Textbooks: The Pendulum of 'Loading' and 'Disarming' History: The Southeastern European Test Case." In Disarming History. International Conference on Combating Stereotypes and Prejudice in History Textbooks of Southeast Europe, 23-27. Stockholm: Nykopia Tryck AB, 1999.

Koulouri, Christina. Clio in the Balkans: The Politics of History Education. Thessaloniki: CDRSEE, 2002.

Murgescu, Mirela-Luminita. "Rewriting School Textbooks as a Tool of Understanding and Stability." Southeast European and Black Sea Studies 2, no. 1 (2002): 90-104. 


\section{THE QUARTERLY JOURNAL}

Murgescu, Mirela-Luminita. "Rewriting School Textbooks as a Tool of Understanding and Stability." Southeast European and Black Sea Studies 2, no. 1 (2002): 90-104.

Simoska, Emilija. "FYR Macedonia." In Clio in the Balkans: The Politics of History Education, 495-97. Thessaloniki: CDRSEE, 2002.

Stefoska, Irena. Macedonian edition., 2005. 